\title{
Advanced Exergoeconomic Analysis of Organic Rankine Cycle Waste Heat Recovery System of a Marine Power Plant
}

\author{
T. Koroglu*1 and O. S. Sogut ${ }^{2}$ \\ Istanbul Technical University, Maritime Faculty, 34940 Istanbul, Turkey \\ E-mail: tukoroglu@itu.edu.tr ${ }^{1}$ sogut@itu.edu.tr ${ }^{2}$
}

Received 21 October 2016, Accepted 03 July 2017

\begin{abstract}
In this paper, superheated and saturated vapor ORCs commonly utilized as waste heat recovery systems of a marine power plant are investigated. First, a parametric study with different organic fluids has been carried out by applying conventional exergy and exergoeconomic analyses to the system considered in order to identify the best possible operating conditions and also to evaluate the findings of conventional exergy-based analyses. Then, advanced exergy and exergoeconomic analyses have been performed on ORCs by splitting exergy destruction rates, exergy destruction costs and investment costs of components and overall system to identify avoidable parts of costs and exergy destructions. Finally, decision criteria were suggested on the selection of more appropriate system depending on the results of the analysis.
\end{abstract}

Keywords: Organic Rankine cycle; advanced exergy; marine power plant; advanced exergoeconomics; organic fluids.

\section{Introduction}

Greenhouse gas (GHG) emissions are identified as one of the pollutants that have a profound effect on human and nature [1]. Even the maritime transportation sector, being known as one of the cleanest sectors [2], is regulated by the instruments put into effect by International Maritime Organization (IMO). GHG emissions of ships are to be decreased by imposing an Energy Efficiency Design Index (EEDI) to new designs and the companies are required to prepare a Ship Energy Efficiency Management Plan (SEEMP) for their ships in service [3-5]. Since fuel prices are expected to rise in the future [6], the ship owners will pay more attention to lowering costs through saving on fuel consumption [7]. Thus, the requirements of IMO will lead ship-owners to own and operate more energy efficient ships.

There are many operational and design measures proposed to lower the fuel consumption thus GHG emissions including weather routing, hydrodynamic form optimization, engine refinements etc. [8]. Waste heat recovery (WHR) systems are more readily available technique to reduce fuel consumption since the most of the world fleet's ships use two-stroke diesel engines [9]. Their exhausts, jacket water coolers and air intercoolers contain tremendous amount of energy to be utilized $[10,11]$. WHR systems could even meet the requirements of electricity onboard for some applications [7]. Utilization of waste heat to produce power or electricity can be realized through the use of a steam cycle, power turbine, thermo-electric generator or organic Rankine cycle (ORC) [11].

ORC-WHR system applications and reviews of research in this area can be traced in the literature for internal combustion engines. Sprouse III and Depcik reviewed and compared ORCs, organic fluids for internal combustion engine (ICE) exhaust WHR systems and showed that it is possible to have up to $20 \%$ efficiency improvement [12].
Vaja and Gambrotta also studied ICE exhaust WHR system by adding ORC with three different organic fluid and carried out thermodynamic analysis with conclusion of improving efficiency around $13 \%$ with using benzene as working fluid [13]. Srinivasan et al. reviewed some studies on exhaust WHR systems and analyzed bottoming ORC after an Advanced Low Pilot Ignited Natural Gas engine to see its impacts on efficiency improvement and gas emissions [14]. Tian et al. analyzed thermodynamic behavior and economical aspects of several organic fluids with respect to some parameters and revealed that R141B shows the highest efficiency and power production values, and the lowest electricity production cost value among others [15]. Some exergy analyses were also conducted on internal combustion engine waste heat recovery organic Rankine systems by several researches. Zhu et al. studied a simple ORC which gains heat only from the exhaust of an ICE with different working fluids and carried out energy and exergy analyses resulting that R113 shows a better performance among others [16]. Mago and Chamra analyzed ICE ORC system by using the exergy topological method and showed that R113 performs the best among other fluids with improvement potential of $10 \%$ exergetic efficiency [17]. Wang et al. simulated two different $10 \mathrm{~kW}$ net power rated WHR ORC systems with a single screw expander for a hypothetical ICE with $600 \mathrm{~K}$ exhaust temperature and investigated several organic fluids in terms of exergy destruction [18]. Wang et al. also analyzed a system combining a gasoline engine with a dual loop ORC which recovers the waste heat from both the exhaust and coolant systems with respect to thermodynamics and exergy destruction analyses [19].

Application of ORC WHR systems for marine power plants are also popular in recent studies. Choi and Kim carried out energy and exergy analyses on a dual loop WHR cycle where upper cycle is water trilateral cycle and lower 
cycle is an organic Rankine cycle which uses exhaust of a 6800 TEU container ship as heat source and results showed that system exergetic efficiency is increased, specific fuel consumption and $\mathrm{CO}_{2}$ emission are decreased [20]. Yun et al. proposed a configurable dual parallel ORC WHR system for marine application as using exhaust gas of a marine engine as split heat source for both parallel ORCs, and compared two different configuration results of energy analysis to those of a single ORC system where they revealed that 50-50\% configuration dual parallel ORC produces more power than single ORC while that configuration produces slightly lower power than $70-30 \%$ configuration [21]. Bellalio et al. investigated a case study of an ORC with R245FA which uses exhaust gases of two 2-stroke main engines and two 4-stroke generators and their four different operation configurations via a thermal oil and concluded that $1^{\text {st }}$ configuration with $85 \%$ loaded main engines and $95 \%$ loaded generators produces more power with less specific fuel consumption and GHG emissions [22]. Song et al. created two cycle ORCs on the basis of a test rig with exhaust and jacket water of inline six-cylinder turbocharged engine for marine propulsion plants as heat sources and optimized them as one cycle which uses both of the heat sources, analyzed with energy, exergy and economic analyses with results of efficiency improvement around 9\% and high economic feasibility of optimized system [23].Yang and Yeh published several studies on marine engine WHR ORC system. They analyzed with respect to energy and exergy analyses and optimized a recuperated jacket water ORC system with 6 different fluids and resulted that R600A performed most satisfactorily [24]. Then, they utilized exhaust gas of a large marine diesel engine via two different ORC system with four different organic fluids, and carried out thermodynamic and economic analyses by introducing a new parameter to optimize economic performance, also they have shown the $\mathrm{CO}_{2}$ emission reduction potential of the system they proposed [25]. In another study of them, they utilized both exhaust and jacket water of large main diesel engine via ORC with 5 different organic fluids and analyzed the system thermo-economically [26]. Yang published a study on a compact WHR ORC on a marine diesel engine with 14 cylinders, and proposed three operating models by using exhaust, jacket water and scavenge air cooler as heat sources, evaluated their economic performance and also reviewed previous studies on ICE WHR systems [27]. Kalikatzarakis and Frangopoulos studied three different ORC systems and 21 working fluids, in order to obtain the optimum thermo-economic solution for a large marine diesel engine [28]. Koroglu and Sogut designed a superheated vapor ORC system after a VLCC marine power plant with four different organic fluids and performed conventional and advanced exergy analyses with respect to different operating conditions and parameters and reported that R113 is the most suitable fluid [29].

Exergy analysis is an evaluation tool for energy systems that relies on the first and the second law of thermodynamics [30] and a relatively new method for ship [31-32] and marine energy applications [23-24,27-28]. However, it has shortcomings on providing additional information as potential of improvement of components and overall system [34], interactions among components [35], and origin of exergy destruction. Advanced exergy analysis is introduced to eliminate these shortcomings and it is recently applied to marine energy systems $[29,36]$.
Exergoeconomic analysis is based on both exergy and conventional economic analysis, with costs associated with all exergy streams including heat and power [30]. It reveals information, which is not available by energy analysis and economics such as cost of exergy destruction. Advanced exergoeconomic analysis is to improve the quality of exergoeconomic analysis results [37]. It gives further insight about the avoidable total investment cost and cost of exergy destruction as well as effects of interactions among system components on the cost of component and origin of costs. Optimization strategies would be misled for complex systems with simultaneously affected components if the interactions among the system components are not considered [38]. Advanced exergoeconomic analysis is applied to many thermal energy systems in the literature [3944]. According to the results of the literature review carried out in this study, the application of the method to a marine energy system has not been performed.

In this paper, an actual five-cylinder two-stroke marine engine power plant with two different combinations and five different organic fluids of simple realistic conceptual ORCs are investigated. Firstly, combination of the ORC system is based on a previous work with enhancements as superheated organic fluid cycle [29]. Secondly saturated organic fluid cycle is introduced. Investigated ORCs are conceptually formed to evaluate the possibility of producing power from waste heat of the main engine and lower the emissions to fulfil energy efficiency design and operation indices. A fully loaded very large crude carrier (VLCC) ship data is used to perform exergy and exergoeconomic analyses. Advanced exergy and exergoeconomic analyses are carried out to reveal avoidable exergy destructions, investment costs and cost of exergy destructions for both systems and components. Also, the most suitable organic fluids among all have been determined in the analyses.

\section{Theoretical Method}

Maximum theoretical work while a system goes a process from its state to reference environment is defined as exergy [45]. For a stream $j$ exergy is formulated as [30]:

$$
\dot{E}_{J} \cong \dot{m}_{j}\left[\left(h_{j}-h_{0}\right)-T_{0}\left(s_{j}-s_{0}\right)\right]
$$

Exergy balances for a component and overall system, exergetic efficiency, $\varepsilon$ and exergy destruction ratio $y_{D}^{*}$ are given respectively as:

$$
\begin{aligned}
& \dot{E}_{D, k}=\dot{E}_{F, k}-\dot{E}_{P, k} \\
& \dot{E}_{F, t o t}=\dot{E}_{P, t o t}+\dot{E}_{D, t o t}+\dot{E}_{L, t o t} \\
& \varepsilon_{k}=\frac{\dot{E}_{P, k}}{\dot{E}_{F, k}} \\
& y_{D, k}^{*}=\frac{\dot{E}_{D, k}}{\dot{E}_{D, t o t}}
\end{aligned}
$$

where $\dot{E}_{F}$ exergy rate of fuel, $\dot{E}_{P}$ exergy rate of product and $\dot{E}_{D}$ exergy destruction rate, subscript $k$ is investigated component and tot is the overall system. Components are assumed to have adiabatic system boundary, while overall system is let heat leak. Hence $\dot{E}_{L, t o t}$ is exergy loss rate of overall system. Exergy analysis determines sources, locations and magnitudes of irreversibilities in a system and also used to compare systems [46]. 
Advanced exergy analysis is applied by splitting exergy destruction into avoidable and unavoidable parts [44]. Unavoidable exergy destruction rate could be calculated via creating an unavoidable cycle with the unavoidable conditions of the components in the system [46]. Unavoidable conditions are described as possible minimum irreversibility rate within the technological, physical, economic and other constraints [34]. Avoidable exergy destruction $\dot{E}_{D, k}^{A V}$ is the difference between real exergy destruction $\dot{E}_{D, k}$ and unavoidable exergy destruction $\dot{E}_{D, k}^{U N}$ as [39]:

$$
\dot{E}_{D, k}^{A V}=\dot{E}_{D, k}-\dot{E}_{D, k}^{U N}
$$

Independent from being a stream, heat or power exergy rate, cost of an exergy stream $j \dot{C}_{j}$, could be calculated as [30]:

$$
\dot{C}_{j}=c_{j} \dot{E}_{j}
$$

where, $c_{j}$ is specific cost per unit of exergy. Similar to exergy analysis, exergoeconomic analysis is based on a cost balance for $k$ th component as [30]:

$$
\sum_{e} \dot{C}_{e, k}=\sum_{i} \dot{C}_{i, k}+\dot{Z}_{k}
$$

where $\sum_{e} \dot{C}_{e, k}$ total cost of exiting exergies, $\sum_{i} \dot{C}_{i, k}$ is total cost of entering exergies, $\dot{Z}_{k}$ is a sum of investment, operation and maintenance costs of $k$ th component. Purchased equipment cost (PEC) is the base value to derive investment, operation and maintenance vs costs of components [30]. PECs of components will be determined by using formulations in the literature [47] due to lack of real cost data of equipment. Also, it could be appropriate to use a cost equation based calculation method to compare different systems with similar components while it provides the same basis when it comes to different values of operating conditions of the same components such as same type heat exchanger area changes with different working fluid and conditions, therefore value of the component varies based on the cost equation. PECs are calculated by the book which refers to the cost value of components in 2000, in that event costs should be brought to the time of calculation, 2015, via using Chemical Engineering Plant Cost Index (CEPCI) $[26,38]$.

$$
P E C_{2015}=P E C_{2000} \frac{C E P C I_{2015}}{C E P C I_{2000}}
$$

Cost balance equation of overall system:

$$
\dot{C}_{P, t o t}=\dot{C}_{F, t o t}+\dot{Z}_{t o t}
$$

where $\dot{C}_{P, t o t}$ cost of product exergy, $\dot{C}_{F, \text { tot }}$ cost of fuel exergy and $\dot{Z}_{\text {tot }}$ is the sum of investment, operation and maintenance cost of overall system. Second equation could be also used for component itself:

$$
c_{P, k} \dot{E}_{P, k}=c_{F, k} \dot{E}_{F, k}+\dot{Z}_{k}
$$

where $c_{P, k}$ and $c_{F, k}$ are average cost per unit of product and fuel exergies respectively. Finally, cost of exergy destruction is [30]:

$$
\dot{C}_{D, k}=c_{F, k} \dot{E}_{D, k}
$$

Advanced exergoeconomic analysis starts with splitting the cost of exergy destruction into unavoidable and avoidable cost of exergy destruction, which could be calculated with respect to the average cost per unit of fuel exergy respectively as [44]:

$$
\begin{aligned}
& \dot{C}_{D, k}^{U N}=c_{F, k} \dot{E}_{D, k}^{U N} \\
& \dot{C}_{D, k}^{A V}=c_{F, k} \dot{E}_{D, k}^{A V}
\end{aligned}
$$

To calculate unavoidable investment cost of a component, the least favorable operating conditions should be assumed as having high irreversibilities. This approach could be applied to heat exchangers for new simulations with these conditions. Nevertheless, unavoidable investment costs for turbine and pump could be predefined as a percentage of the original cost [41]. Avoidable total investment cost could be calculated as:

$\dot{Z}_{k}^{A V}=\dot{Z}_{k}-\dot{Z}_{k}^{U N}$

To determine average costs per unit of fuel and product exergies of a component by solving cost balance equation, auxiliary cost equations are required, which could be determined from the literature [30, 43].

\section{System Description}

The ORC WHR system of a marine power plant considered in this study is conceptually constructed on exhaust (Exh) and main jacket cooler (JW) systems of the marine diesel engine from a VLCC ship engine room. Exhaust gases from the diesel engine exit turbocharger then enter exhaust boiler. In the exhaust boiler, superheated, and saturated steam is produced both for turbogenerator to generate electricity and for domestic hot water. Thus, there is an already WHR system installed in the investigated ship. At the end of the exhaust boiler, before to be discharged to atmosphere, exhaust gases still have a relatively high temperature above Sulphur corrosion point $\left(160^{\circ} \mathrm{C}\right)$ [48], thus a closed ORC system can be utilized. General information of investigated ship and main engine is in Table1 and the VLCC data at fully loaded condition for this study is given in Table 2 [29]. The VLCC ship has a constant seawater (SW) inlet temperature, pressure and mass flow rate as $20^{\circ} \mathrm{C}, 4.29 \mathrm{bar}, 335.24 \mathrm{t} / \mathrm{h}$ respectively. Finally, shaft generator power at this condition is $284.32 \mathrm{~kW}$.

Table 1. Particulars of ship and main engine.

\begin{tabular}{llll}
\hline \multicolumn{1}{c}{ Ship } & \multicolumn{3}{c}{ Main Engine } \\
\hline $\begin{array}{l}\text { Length } \\
\text { overall }\end{array}$ & $305 \mathrm{~m}$ & Cylinder bore & $90 \mathrm{~cm}$ \\
Draught & $19 \mathrm{~m}$ & Stroke & $292 \mathrm{~cm}$ \\
Breadth & $47 \mathrm{~m}$ & MCR Power & $18 \mathrm{MW}$ \\
Depth & $30.4 \mathrm{~m}$ & MCR Engine Speed & $74 \mathrm{RPM}$ \\
Deadweight & 178720 & Specific Fuel & 168 \\
& tons & Consumption & $\mathrm{g} / \mathrm{kWh}$ \\
\hline
\end{tabular}

Superheated ORC systems is designed with an economizer, evaporator with pump and drum, and superheater attached to exhaust system of main engine. This ORC system also has a pump, preheater, recuperator, exhaust system components mentioned before, turbine and a condenser. Working organic fluid is pumped to preheater to be heated, then it is sent to recuperator to gain more heat using energy of expanded superheated vapor. In the economizer, exhaust gas of the main engine brings organic fluid to saturated fluid phase. Evaporator, also coupled with exhaust system, brings the working fluid into saturated vapor 


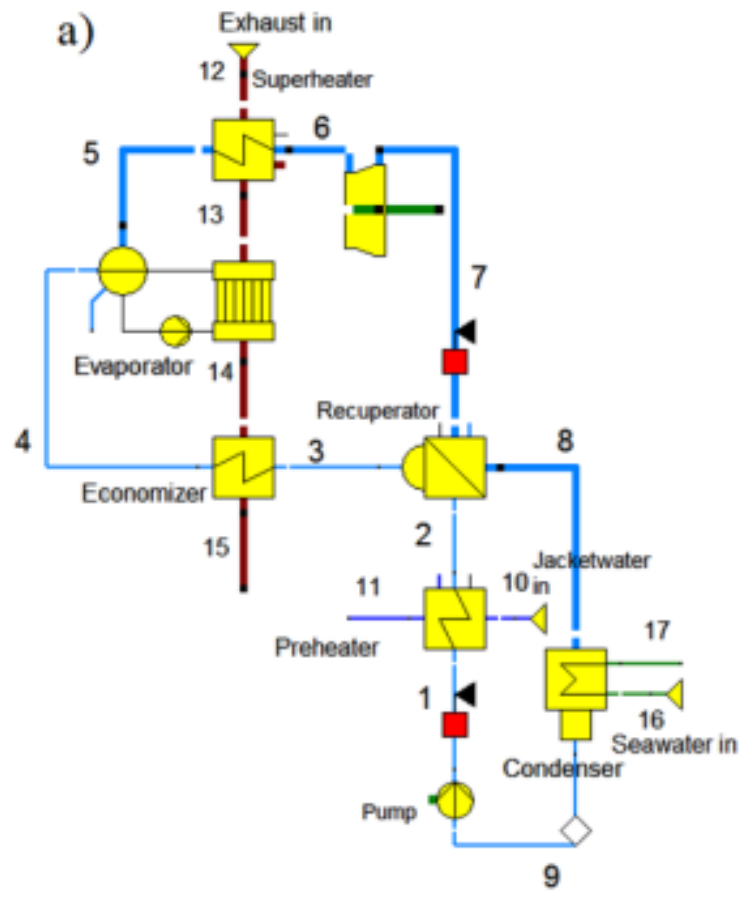

b)

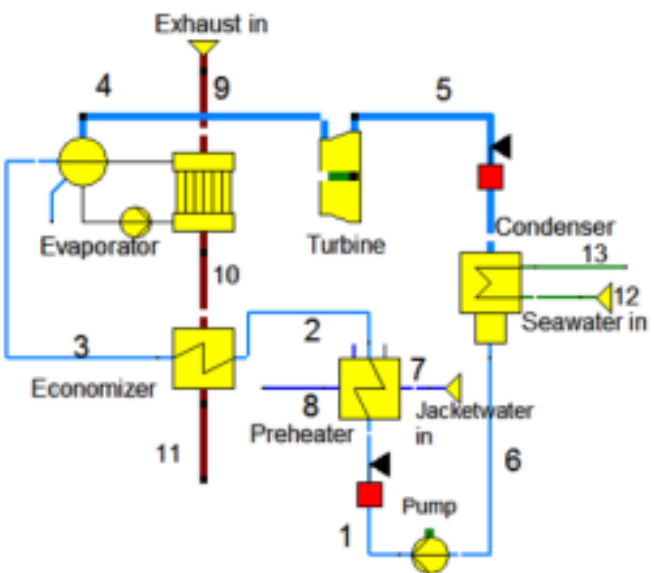

Figure 1. General schematic of a) superheated ORC b) saturated ORC systems.

phase. Superheater heats saturated working fluid until a certain point of superheat. Then superheated fluid expands in the turbine to produce power. After recuperator, fluid condenses in the condenser. Schematic diagram of the system can be seen in Figure 1a. Saturated system does not have the components of the superheater and the recuperator as it is shown in Figure 1b. In this cycle, saturated vapor is directly expanded in the turbine. Then it is cooled down until it reaches saturated liquid state in the condenser. Systems are designed and run in Ebsilon Professional Software [49].

Ebsilon Professional is commercial software that is used to design and simulate, evaluate and optimize energy and power plant systems. It has libraries of components that are used in power plants. Also it has capability to program designer's own components and processes. There are plenty of studies that uses Ebsilon Professional to analyze thermodynamics cycles and energy systems in the literature such as $[38,50]$.

Table 2. VLCC ship data used in this study.

\begin{tabular}{ccccccc}
\hline $\begin{array}{c}\text { Engine } \\
\begin{array}{c}\text { Speed } \\
(\mathrm{RPM})\end{array}\end{array}$ & $\begin{array}{c}\mathrm{MEP} \\
(\mathrm{MW})\end{array}$ & $\begin{array}{c}\mathrm{T}_{\text {Exh }} \\
\left({ }^{\circ} \mathrm{C}\right)\end{array}$ & $\begin{array}{c}\dot{m}_{\text {Exh }} \\
(\text { ton } / \mathrm{h})\end{array}$ & $\begin{array}{c}\mathrm{JW} \mathrm{T}_{\text {out }} \\
\left({ }^{\circ} \mathrm{C}\right)\end{array}$ & $\begin{array}{c}\text { JW P } \\
(\text { bar })\end{array}$ & $\begin{array}{c}\dot{m}_{J W} \\
(\text { ton } / \mathrm{h})\end{array}$ \\
\hline 74 & 17.03 & 186.68 & 171.65 & 79.98 & 3.08 & 220.45 \\
\hline
\end{tabular}

Organic fluids are selected as working fluids for WHR ORC systems from previous works of R141B [15], R601 and R601A [48], R113 [12, 16-17], and R245FA analyzed in [15, 23-24, 48, 51-54]. They are selected considering their working temperatures, pressures and performances among other organic fluids [29] and are given in Table 3. Referring the literature and ASHRAE Standards [55], their safety value, type of fluid pump and turbine outlet pressures for both systems are also included in Table 3.

ASHRAE safety standards A and B denote lower and higher toxicity respectively while increasing numbers represent increasing flammability [55]. No information about the safety of R141B is found in ASHRAE Standards document [55]. Fluid type is described as the slope of saturated vapor curve on T-s diagram of the fluid. Positive and negative slope represent wet and dry respectively while slope approximately zero represents isentropic fluid [51].

Unavoidable conditions of the system components are assumed considering previous studies in literature and expert opinion due to lack of unavoidable conditions data [56]. Economizers, evaporators and condensers do not have any temperature difference conditions due to assuming saturated fluid or vapor as their outlet conditions. Table 4 shows assumed real, unavoidable and unavoidable cost conditions of investigated components. It should be noted that all conditions have the same value for superheated ORC and saturated ORC.

Total investment costs of components are calculated as mentioned in section 2 with the assumptions of 30 years of life, interest rate of $12.75 \%$, operation and maintenance cost is $6 \%$ of total investment cost, $161.5 \$ /$ t fuel price, 8000 working hours in a year, lower heating value of the fuel is $39,466 \mathrm{MJ} / \mathrm{kg}$ [57]. The economic assumptions are made with the knowledge from earlier studies in literature and serve as a basis for comparison for different system configurations. Also, it is important to determine universal heat transfer coefficients of heat exchangers from literature [58] due to calculations of their total investment costs.

\section{Analysis}

Real cycles of superheated and saturated ORCs are designed with respect to the data given in Tables 3 and 4 . Due to corrosion risk, minimum stack temperature is fixed at $160^{\circ} \mathrm{C}$. Thermodynamic data of the conceptual cycles are generated.

By keeping turbine power output constant, unavoidable cycles are created for both combinations of ORCs. Hence, mass flow rate of the working fluid and exhaust stack temperature is let to vary. Unavoidable exergy destruction of each component is calculated by simply applying exergy balance to each component. Then, avoidable exergy destructions are determined by Eq. (6). Later, exergy and advanced exergy analyses of ORC systems are carried out. 
Table 3. Organic fluids and their conditions.

\begin{tabular}{|c|c|c|c|c|c|c|}
\hline \multirow[b]{2}{*}{ Fluid } & \multirow[b]{2}{*}{ ASHRAE Safety } & \multirow[b]{2}{*}{ Type } & \multicolumn{2}{|c|}{ Saturated ORC } & \multicolumn{2}{|c|}{ Superheated ORC } \\
\hline & & & $\begin{array}{c}\text { Pump Out } P \\
\text { (bar) }\end{array}$ & $\begin{array}{l}\text { Turbine Out } P \\
\text { (bar) }\end{array}$ & $\begin{array}{c}\text { Pump Out } P \\
\text { (bar) }\end{array}$ & $\begin{array}{c}\text { Turbine Out } P \\
\text { (bar) }\end{array}$ \\
\hline R113 & A1 & Dry & 15 & 0.5 & 10.8 & 0.55 \\
\hline $\mathrm{R} 141 \mathrm{~B}$ & & Dry & 22 & 0.8 & 19.3 & 1.5 \\
\hline R245FA & B1 & Dry & 35.4 & 1.5 & 24 & 1.5 \\
\hline R601 & A3 & Dry & 19 & 1.1 & 17 & 1.2 \\
\hline R601A & A3 & Dry & 22.5 & 1.1 & 20 & 1.5 \\
\hline
\end{tabular}

Table 4. Assumed real, unavoidable and unavoidable cost conditions of components.

\begin{tabular}{|c|c|c|c|}
\hline Component & Real & Unavoidable & Unavoidable Cost \\
\hline Pump & $\eta=0.8$ & $\eta=0.9$ & $\dot{Z}_{k}^{U N}=60 \%$ of $\dot{Z}_{k}[59]$ \\
\hline Preheater & $\begin{array}{c}\Delta P_{\text {cold }}=0.2 \mathrm{bar} \\
\Delta P_{\text {hot }}=0.2 \mathrm{bar} \\
\Delta T_{\text {Min }}=8{ }^{\circ} \mathrm{C}\end{array}$ & $\begin{array}{c}\Delta P_{\text {cold }}=0.1 \mathrm{bar} \\
\Delta P_{\text {hot }}=0.1 \mathrm{bar} \\
\Delta T_{\text {Min }}=3{ }^{\circ} \mathrm{C}\end{array}$ & $\begin{array}{c}\Delta P_{\text {cold }}=0.3 \mathrm{bar} \\
\Delta P_{\text {hot }}=0.3 \mathrm{bar} \\
\Delta T_{\text {Min }}=11^{\circ} \mathrm{C}\end{array}$ \\
\hline Recuperator & $\begin{array}{c}\Delta P_{\text {cold }}=0.2 \mathrm{bar} \\
\Delta P_{\text {hot }}=0.05 \mathrm{bar} \\
\Delta T_{\text {Min }}=8{ }^{\circ} \mathrm{C}\end{array}$ & $\begin{array}{c}\Delta P_{\text {cold }}=0.05 \mathrm{bar} \\
\Delta P_{78}=0.02 \mathrm{bar} \\
\Delta T_{\text {Min }}=3{ }^{\circ} \mathrm{C}\end{array}$ & $\begin{array}{c}\Delta P_{\text {cold }}=0.3 \mathrm{bar} \\
\Delta P_{78}=0.08 \mathrm{bar} \\
\Delta T_{\text {Min }}=11^{\circ} \mathrm{C}\end{array}$ \\
\hline Economizer & $\begin{array}{c}\Delta P_{\text {cold }}=0.15 \mathrm{bar} \\
\Delta P_{\text {hot }}=0.01 \mathrm{bar} \\
x_{3}=0\end{array}$ & $\begin{array}{c}\Delta P_{\text {cold }}=0.1 \text { bar } \\
\Delta P_{\text {hot }}=0.003 \text { bar } \\
x_{3}=0\end{array}$ & $\begin{array}{c}\Delta P_{\text {cold }}=0.25 \mathrm{bar} \\
\Delta P_{\text {hot }}=0.02 \mathrm{bar} \\
x_{3}=0\end{array}$ \\
\hline Evaporator & $\begin{array}{c}\eta_{P}=0.8 \\
\Delta P_{\text {Circ }}=0.1 \mathrm{bar} \\
\Delta P_{\text {hot }}=0.005 \mathrm{bar} \\
\Delta T_{A p p}=3{ }^{\circ} \mathrm{C}\end{array}$ & $\begin{array}{c}\eta_{P}=0.9 \\
\Delta P_{\text {Circ }}=0.06 \mathrm{bar} \\
\Delta P_{\text {hot }}=0.003 \mathrm{bar} \\
\Delta T_{A p p}=1{ }^{\circ} \mathrm{C}\end{array}$ & $\begin{array}{c}\eta_{P}=0.6 \\
\Delta P_{\text {Circ }}=0.15 \mathrm{bar} \\
\Delta P_{\text {hot }}=0.01 \mathrm{bar} \\
\Delta T_{A p p}=5^{\circ} \mathrm{C}\end{array}$ \\
\hline Superheater & $\begin{array}{c}x_{5}=1 \\
\Delta P_{\text {cold }}=0.15 \text { bar } \\
\Delta P_{\text {hot }}=0.005 \text { bar } \\
\Delta T_{\text {Min }}=8{ }^{\circ} \mathrm{C}\end{array}$ & $\begin{array}{c}x_{5}=1 \\
\Delta P_{\text {cold }}=0.08 \text { bar } \\
\Delta P_{\text {hot }}=0.003 \text { bar } \\
\Delta T_{\text {Min }}=3^{\circ} \mathrm{C}\end{array}$ & $\begin{array}{c}x_{5}=1 \\
\Delta P_{\text {cold }}=0.2 \text { bar } \\
\Delta P_{\text {hot }}=0.01 \text { bar } \\
\Delta T_{\text {Min }}=11^{\circ} \mathrm{C}\end{array}$ \\
\hline Turbine & $\eta_{T}=0.87$ & $\eta_{T}=0,92$ & $\dot{Z}_{k}^{U N}=90 \%$ of $\dot{Z}_{k}$ \\
\hline Condenser & $\begin{array}{l}\Delta P_{\text {hot }}=0.02 \mathrm{bar} \\
\Delta P_{\text {cold }}=0.3 \mathrm{bar}\end{array}$ & $\begin{array}{l}\Delta P_{\text {hot }}=0.01 \mathrm{bar} \\
\Delta P_{\text {cold }}=0.1 \mathrm{bar}\end{array}$ & $\begin{array}{l}\Delta P_{\text {hot }}=0.02 \text { bar } \\
\Delta P_{\text {cold }}=0.4 \text { bar }\end{array}$ \\
\hline
\end{tabular}

Table 5. Exergoeconomic cost balance and auxiliary equations of ORC systems.

\begin{tabular}{|c|c|c|}
\hline Component & Saturated ORC Exergoeconomic Analysis & Superheated ORC Exergoeconomic Analysis \\
\hline Pump & $c_{w} \dot{W}_{P}+\dot{Z}_{P}=c_{1} \dot{E}_{1}-c_{6} E_{6}$ & $c_{w} \dot{W}_{P}+\dot{Z}_{P}=c_{1} \dot{E}_{1}-c_{9} \dot{E}_{9}$ \\
\hline Preheater & $c_{7} \dot{E}_{7}-c_{8} \dot{E}_{8}+\dot{Z}_{P H}=c_{2} \dot{E}_{2}-c_{1} \dot{E}_{1}$ & $c_{10} \dot{E}_{10}-c_{11} \dot{E}_{11}+\dot{Z}_{P H}=c_{2} \dot{E}_{2}-c_{1} \dot{E}_{1}$ \\
\hline Recuperator & & $\begin{array}{c}c_{7} \dot{E}_{7}-c_{8} \dot{E}_{8}+\dot{Z}_{R e c u p}=c_{3} \dot{E}_{3}-c_{2} \dot{E}_{2} \\
c_{7}=c_{8}\end{array}$ \\
\hline Economizer & $\begin{array}{c}c_{10} \dot{E}_{10}-c_{11} \dot{E}_{11}+\dot{Z}_{E c o n}=c_{3} \dot{E}_{3}-c_{2} \dot{E}_{2} \\
c_{10}=c_{11}\end{array}$ & $\begin{array}{c}c_{14} \dot{E}_{14}-c_{15} \dot{E}_{15}+\dot{Z}_{E c o n}=c_{4} \dot{E}_{4}-c_{3} \dot{E}_{3} \\
c_{14}=c_{15}\end{array}$ \\
\hline Evaporator & $c_{9} \dot{E}_{9}-c_{10} \dot{E}_{10}+\dot{Z}_{E v a p}=c_{4} \dot{E}_{4}-c_{3} \dot{E}_{3}$ & $c_{13} \dot{E}_{13}-c_{14} \dot{E}_{14}+\dot{Z}_{\text {Evap }}=c_{5} \dot{E}_{5}-c_{4} \dot{E}_{4}$ \\
\hline & $\begin{array}{c}c_{9}=c_{10} \\
c_{9}=0.01625 \$ / k W h\end{array}$ & $c_{13}=c_{14}$ \\
\hline Superheater & & $\begin{array}{c}c_{12} \dot{E}_{12}-c_{13} \dot{E}_{13}+\dot{Z}_{\text {Sup }}=c_{6} \dot{E}_{6}-c_{5} \dot{E}_{5} \\
c_{12}=c_{13} \\
c_{12}=0.01625 \$ / \mathrm{kWh}\end{array}$ \\
\hline Turbine & $\begin{array}{c}c_{4} \dot{E}_{4}-c_{5} \dot{E}_{5}+\dot{Z}_{T}=c_{w} \dot{W}_{T} \\
c_{4}=c_{5}\end{array}$ & $\begin{array}{c}c_{6} \dot{E}_{6}-c_{7} \dot{E}_{7}+\dot{Z}_{T}=c_{w} \dot{W}_{T} \\
c_{6}=c_{7}\end{array}$ \\
\hline Condenser & $\begin{array}{c}c_{5} \dot{E}_{5}-c_{6} \dot{E}_{6}+\dot{Z}_{\text {Cond }}=c_{13} \dot{E}_{13}-c_{12} \dot{E}_{12} \\
c_{5}=c_{6} \\
c_{12}=0\end{array}$ & $\begin{array}{c}c_{8} \dot{E}_{8}-c_{9} \dot{E}_{9}+\dot{Z}_{\text {Cond }}=c_{17} \dot{E}_{17}-c_{16} \dot{E}_{16} \\
c_{8}=c_{9} \\
c_{16}=0\end{array}$ \\
\hline
\end{tabular}


To analyze both ORC systems exergoeconomically, first their purchased equipment costs are calculated using formulations in [47]. These costs depend on variables such as power, flow rate, heat transfer coefficient. Then, total investment costs are determined for a constant yearly value within its 30-year lifetime. Exergoeconomic cost balances are formulated for each component with total investment costs and auxiliary equations as shown in Table 5. Specific cost per unit of exergy for each exergy stream is calculated. After that, average cost per unit of fuel exergies are determined to calculate costs of real, unavoidable and avoidable exergy destructions. Unavoidable cost conditions given in Table 4 are applied to calculate unavoidable total investment costs of the components. Finally, avoidable investment costs are determined by Eq. (15) to conclude advanced exergoeconomic analysis.

All investment costs cannot be provided due to ten different cycles creating ten different investment costs for each component. That means, investment costs of components change with respect to the cycle and the fluid itself.

Deciding auxiliary equations could be arbitrary as well as found in [30]. Moreover, costs for per exergy unit of exhaust exergy and jacket water are assumed as equal due being byproduct of the same component (main engine) [30]. Specific cost of exhaust stream calculated by using the fuel price divided by lower heating value of the fuel as given in section 3. Specific cost of condenser seawater inlet exergy assumed to be zero, because it is already used onboard.

\section{Results and Discussion}

In this section, exergy, exergoeconomic, advanced exergy and advanced exergoeconomic analyses results are presented for overall systems. As it is shown in Figure 2, net power output of saturated ORCs is higher than superheated ORCs except for R601. The highest value of net power output belongs to R141B for saturated ORC as $324.02 \mathrm{~kW}$ and R113 for superheated ORC as $295.25 \mathrm{~kW}$.

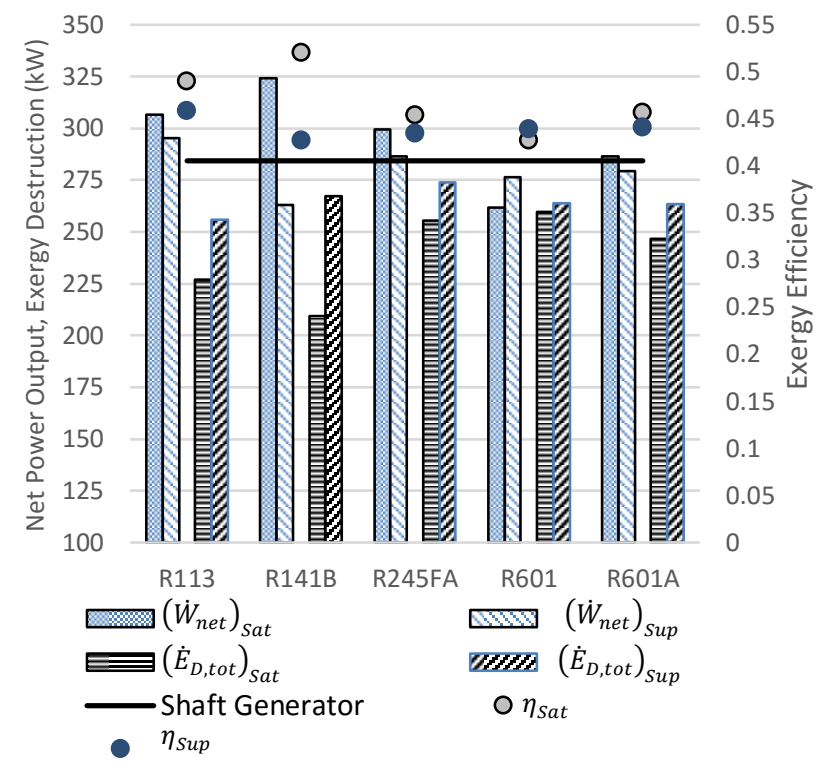

Figure 2. Net power output, exergy destruction rates and exergy efficiencies of saturated and superheated ORC systems.

The lowest value of net power output belongs to R601 for saturated ORC as $261.74 \mathrm{~kW}$ and R141B for superheated ORC as $262.98 \mathrm{~kW}$. Compared to shaft generator power output of $284.32 \mathrm{~kW}$ as threshold; it is observed that R141B, R113, R245FA and R601A in saturated ORC produce more than that of shaft generator. In superheated ORC, only R113 and R245FA working fluids produce more than shaft generator threshold.

The highest exergy efficiency of overall system in saturated ORC is experienced with R141B fluid as 0.52 and the lowest value with R601 as 0.438. In superheated ORC, the highest efficiency belongs to R113 as 0.459 while the lowest belongs to R141B as 0.427 . Exergy efficiencies show similar trend as net power outputs of investigated systems due to supplied heat rate is the same from exhaust boiler. Finally, total exergy destructions are higher in superheated ORC than saturated ORC for each case. The lowest exergy destruction rate is within saturated ORC with R141B as $209.33 \mathrm{~kW}$ and superheated ORC with R601A as $263.47 \mathrm{~kW}$.

In Figure 3, results of exergoeconomic analyses applied to overall systems of saturated and superheated ORCs are shown. Total investment cost $\dot{Z}_{\text {tot }}$ for saturated ORCs are lower than superheated ORCs except for R141B. The highest value of total investment cost for saturated ORC is at R141B as $8.79 \$ / \mathrm{h}$ while the lowest is at R601 as $7.94 \$ / \mathrm{h}$. Superheated ORC with R601A has the highest value of total investment cost as $9.12 \$ / \mathrm{h}$ while the lowest is at R141B as $8.13 \$ / \mathrm{h}$

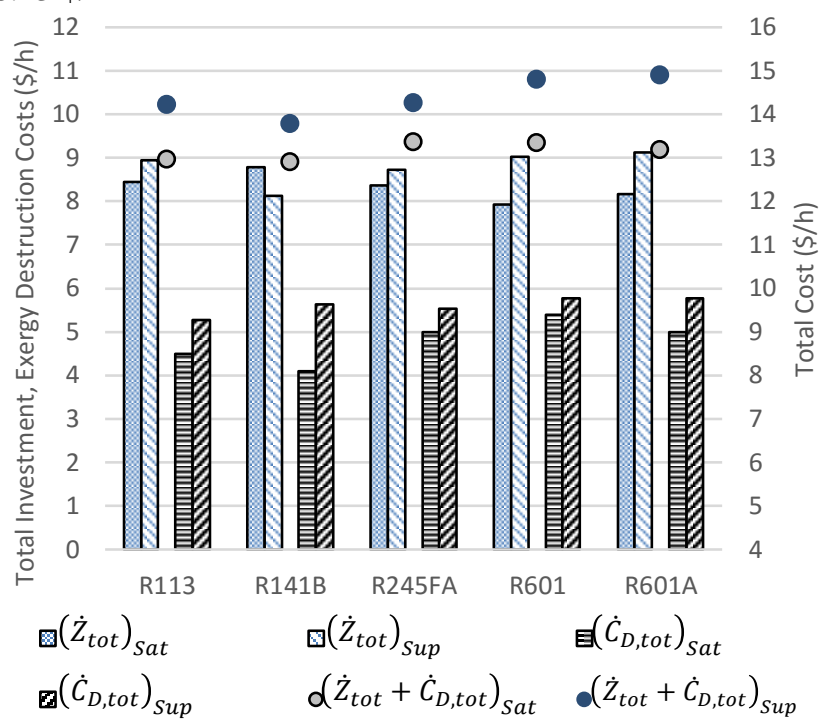

Figure 3. Total investment cost, exergy destruction costs and total costs of saturated and superheated ORC systems.

Superheated ORC systems have higher total cost $\left(\dot{Z}_{\text {tot }}+\right.$ $\left.\dot{C}_{D, t o t}\right)$ than saturated ORC systems. However, the smallest difference occurs for R141B while the greatest difference is for R601A. Moreover, the highest total cost belongs to R601A (14.89 \$/h) while the lowest belongs to R141B $(13.77 \$ / \mathrm{h})$ for superheated ORC. In contrast, the highest is at R245FA (13.35 $\$ / \mathrm{h}$ ) for saturated ORC. But, the lowest total cost is also calculated at R141B (12.89 $\$ / \mathrm{h})$ for saturated ORC. Finally, exergy destruction costs are higher for superheated ORC systems than saturated ORC systems. The highest value of exergy destruction cost is determined at R601 (5.39 \$/h) while the lowest is at R141B (4.1 \$/h) for saturated ORC. R601 and R601A fluid have the highest (5.77 $\$ / \mathrm{h})$ and R113 has the lowest $(5.28 \$ / \mathrm{h})$ exergy destruction cost for superheated ORC.

Results of advanced exergy analyses applied to both systems with all organic fluids are shown in Figure 4. Unavoidable exergy destructions are higher in superheated 
ORC than saturated ORC except R601. Moreover, R601 system has almost the same unavoidable exergy destructions for both ORCs. The highest value of unavoidable exergy destruction belongs to R601 (190.11 kW), while the lowest belongs to R141B (144.75 kW) for saturated ORC. R245FA fluid has almost the same avoidable exergy destruction for both ORC system combinations. Other fluid cycles have close values of avoidable exergy destructions. The highest avoidable exergy destruction is occurred at R601 $(80.02 \mathrm{~kW})$ and the lowest is at R141B $(64.58 \mathrm{~kW})$ for saturated ORC systems. For superheated ORC systems, R601A has the highest avoidable exergy destruction $(75.48 \mathrm{~kW})$ among all while R245FA has the lowest $(70.1 \mathrm{~kW})$.

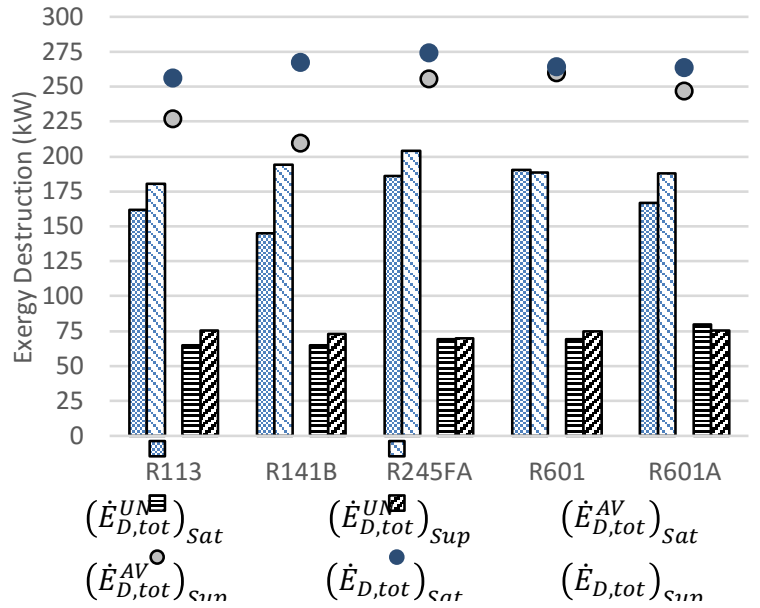

Fig. 4. Results of advanced exergy analysis for saturated and superheated ORC systems.

Figure 5 shows the splitting of exergy destruction costs into avoidable and unavoidable parts. Unavoidable exergy destruction costs are higher for all fluids of superheated ORCs than saturated ORCs.

Avoidable exergy destruction costs have similar trends with avoidable exergy destructions. The highest values of avoidable exergy destruction cost belong to R601A as 1.63 $\$ / \mathrm{h}$ for saturated ORC and as $1.54 \$ / \mathrm{h}$ for superheated ORC. The lowest values of avoidable exergy destruction cost belong to R113 as 1.29 \$/h for saturated ORC and R245FA as $1.43 \$ / \mathrm{h}$ for superheated ORC.

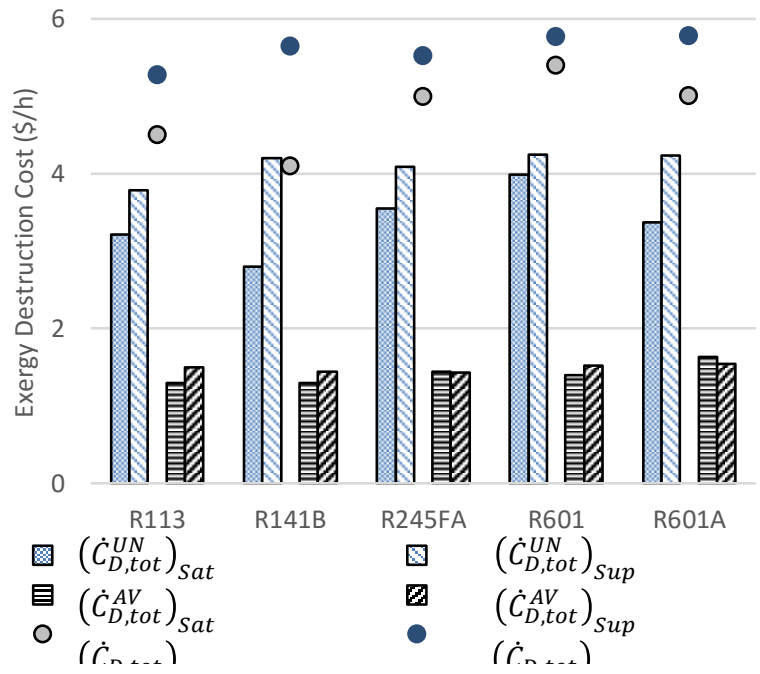

Figure 5. Results of splitting exergy destruction costs for saturated and superheated ORC systems.

Figure 6 shows that the most of the total investment cost is unavoidable for all system and fluid combinations. Also, all avoidable total investment costs are lower than exergy destruction costs for all combinations of systems and fluids. That means, improvement efforts should be directed to exergy destruction costs rather than total investment costs.

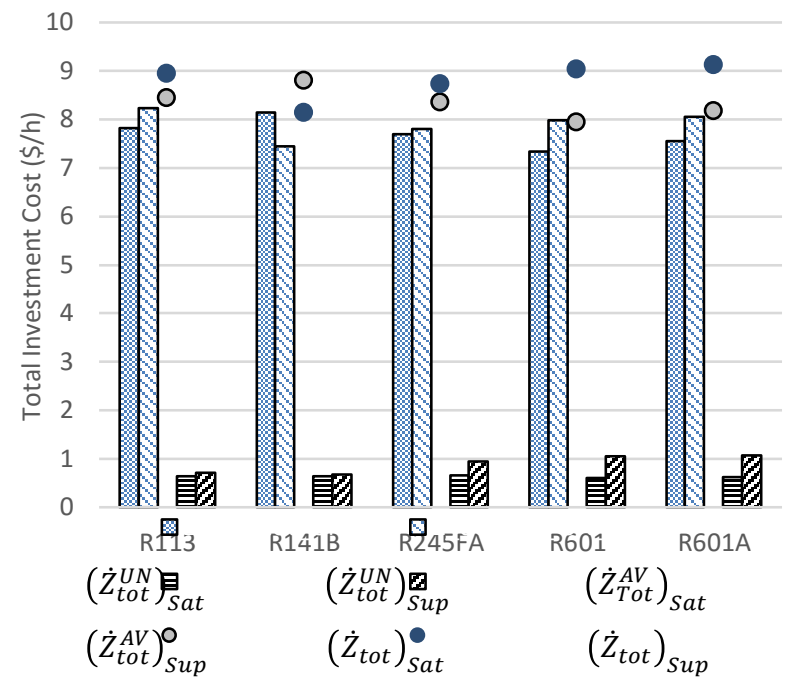

Figure 6. Results of splitting total investment costs for saturated and superheated ORC systems.

Unavoidable total investment costs for both ORCs with R245FA approximately the same. Besides R141B, all fluids have higher unavoidable total investment costs in superheated ORCs than saturated ORCs.

Moreover, avoidable total investment costs for all fluids in superheated ORCs are higher than saturated ORCs. The highest total investment cost is determined at R245FA (0.66 $\$ / \mathrm{h})$ for saturated ORC and R601A $(1.07 \$ / \mathrm{h})$ for superheated ORC. The lowest is occurred at R113 $(0.63 \$ / \mathrm{h})$ for saturated ORC and R141B (0.68 \$/h) for superheated ORC system.

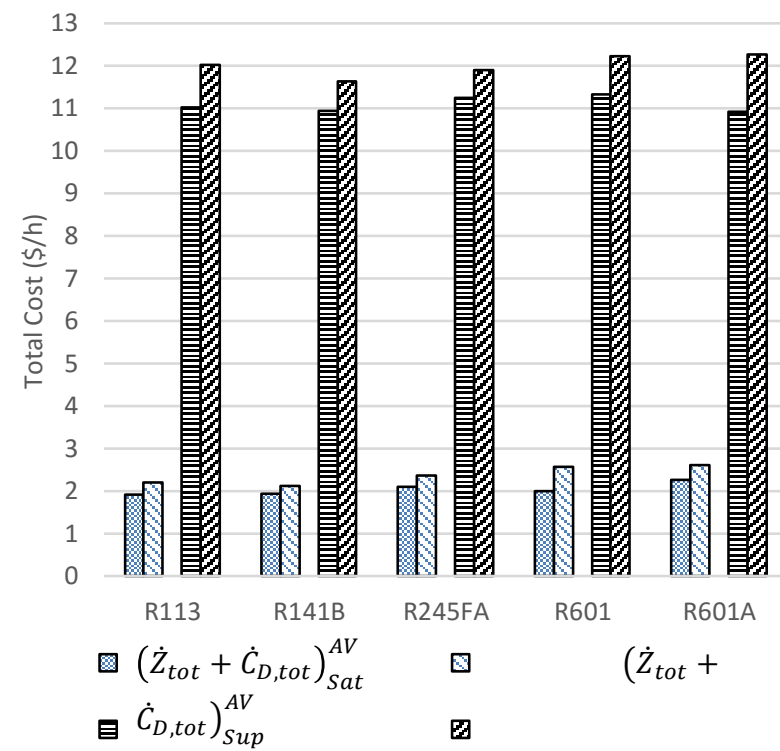

Figure 7. Splitting total costs for saturated and superheated ORC systems.

Finally, avoidable and unavoidable total costs of fluids and system combinations are shown in Figure 7. Avoidable total costs for superheated ORCs are higher than saturated ORCs for all fluids. The highest value belongs to R601A for both ORC cases while the lowest value is calculated at R113 for saturated ORC and R141B for superheated ORC system.

Even, it is possible to avoid some of the total cost for each combination, R601A has the highest unavoidable total cost 
for superheated ORC while R601 for saturated ORC. The lowest unavoidable total cost for saturated ORC belongs to R601A, second lowest is to R141B while the lowest unavoidable total cost belongs to R141B for superheated ORC. Unavoidable total cost is the total cost which cannot be eliminated due to technological developments etc.

With respect to results of analyses shown above, it could be expressed that there must be a trade-off among analyses. Exergy analyses revealed that best fluid for saturated ORC system is R141B while R113 for superheated ORC due to their highest exergy efficiency, net power output and lowest total exergy destructions. It is also shown that, some of cases could fulfill the electricity need of ship without using a shaft generator. On the other hand, exergoeconomic analyses showed that R141B is the most suitable fluid for both ORC combinations with respect to its lowest total cost. Advanced exergy analyses revealed that there is more room for improvement for both combinations of ORCs with R601A due to its highest avoidable exergy destructions. However, minimum reachable exergy destruction is the unavoidable exergy destruction which belongs to R141B (144.75 kW) for saturated ORC. Similarly, advanced exergoeconomic analyses suggested the same result with respect to the avoidable total cost for both ORC system combinations with R601A. However, its net power output is below shaft generator threshold for superheated ORC and on threshold $(286.32 \mathrm{~kW})$ for saturated ORC. R141B could be selected as the best suitable organic fluid for saturated ORC with respect to its high power output, efficiency and slightly higher unavoidable cost. Thermodynamic data of saturated vapor ORC with R141B could be found on Table 6.

Table 6. Thermodynamic data of saturated vapor ORC

\begin{tabular}{|c|c|c|c|c|c|}
\hline Stream & $\begin{array}{l}\dot{m}_{j} \\
\mathrm{~kg} / \mathrm{s}\end{array}$ & $\begin{array}{l}P \\
\text { bar }\end{array}$ & $\begin{array}{l}T \\
{ }^{\circ} \mathrm{C}\end{array}$ & $\begin{array}{l}h \\
\mathrm{~kJ} / \mathrm{kg}\end{array}$ & $\begin{array}{l}s \\
\mathrm{~kJ} / \mathrm{kgK}\end{array}$ \\
\hline 1 & 3.854 & 22 & 26.14 & 230.73 & 1.1014 \\
\hline 2 & 3.854 & 21.7 & 68.98 & 281.38 & 1.2595 \\
\hline 3 & 3.854 & 21.45 & 155.37 & 396.92 & 1.5594 \\
\hline 4 & 3.854 & 21.45 & 160.37 & 537.72 & 1.8844 \\
\hline 5 & 3.854 & 0.8 & 58.659 & 481.66 & 1.9427 \\
\hline 6 & 3.854 & 0.77 & 24.458 & 227.86 & 1.0975 \\
\hline 7 & 61.236 & 3.08 & 79.98 & 335.07 & 1.0750 \\
\hline 8 & 61.236 & 2.78 & 79.226 & 331.88 & 1.0660 \\
\hline 9 & 47.681 & 1.033 & 186.68 & 188.82 & 7.2977 \\
\hline 10 & 47.681 & 1.023 & 175.568 & 177.47 & 7.2755 \\
\hline 11 & 47.681 & 1.003 & 166.417 & 168.13 & 7.2601 \\
\hline 12 & 93.122 & 4.29 & 20 & 83.730 & 0.2967 \\
\hline 13 & 93.122 & 3.89 & 22.537 & 94.234 & 0.3324 \\
\hline
\end{tabular}

Moreover, R141B has also the lowest total cost for superheated ORC. But, it could not be considered as a suitable combination due to producing net power output lower than shaft generator threshold. Second lowest total cost is occurred with combination of R113 and superheated ORC. Advanced exergy analyses revealed that the lowest unavoidable exergy destruction $(180.58 \mathrm{~kW})$ and the second highest avoidable exergy destruction (75.17 $\mathrm{kW}$ ) after R601A belong to R113 for superheated ORC. Besides $\mathrm{R} 141 \mathrm{~B}$, advanced exergoeconomic analyses showed that R245FA has the lowest unavoidable total cost while having the third highest avoidable total cost for superheated ORC.
On the other hand, R245FA has the highest unavoidable exergy destruction with the lowest avoidable exergy destruction. Its, power output, exergy efficiency are lower and total cost is higher than R113. In the end, it could be recommended to use R113 for superheated ORC system. Thermodynamic data of saturated vapor ORC with R113 could be found on Table 7 .

Table 7. Thermodynamic data of superheated vapor ORC.

\begin{tabular}{llllll}
\hline Stream & $\dot{\mathrm{m}}_{\mathrm{j}}$ & $\mathrm{P}$ & $\mathrm{T}$ & $\mathrm{h}$ & $\mathrm{s}$ \\
& $\mathrm{kg} / \mathrm{s}$ & $\mathrm{bar}$ & ${ }^{\circ} \mathrm{C}$ & $\mathrm{kJ} / \mathrm{kg}$ & $\mathrm{kJ} / \mathrm{kgK}$ \\
\hline 1 & 6.392 & 10.8 & 29.24 & 226.93 & 1.0913 \\
2 & 6.392 & 10.7 & 76.98 & 272.03 & 1.2297 \\
3 & 6.392 & 10.65 & 98.32 & 293.06 & 1.2880 \\
4 & 6.392 & 10.55 & 141.10 & 337.48 & 1.4011 \\
5 & 6.392 & 10.55 & 142.10 & 443.80 & 1.6572 \\
6 & 6.392 & 10.47 & 183.68 & 479.58 & 1.7396 \\
7 & 6.392 & 0.55 & 109.23 & 432.49 & 1.7504 \\
8 & 6.392 & 0.53 & 79.98 & 411.47 & 1.6948 \\
9 & 6.392 & 0.52 & 28.83 & 226.20 & 1.0911 \\
10 & 61.236 & 3.08 & 79.98 & 335.07 & 1.0750 \\
11 & 61.236 & 2.98 & 78.86 & 330.36 & 1.0617 \\
12 & 47.681 & 1.033 & 186.68 & 188.82 & 7.2977 \\
13 & 47.681 & 1.03 & 181.99 & 184.03 & 7.2881 \\
14 & 47.681 & 1.027 & 168.04 & 169.78 & 7.2571 \\
15 & 47.681 & 1.024 & 162.20 & 163.82 & 7.2444 \\
16 & 93.122 & 4.29 & 20 & 83.730 & 0.2967 \\
17 & 93.122 & 4.19 & 23.06 & 96.448 & 0.3399 \\
\hline
\end{tabular}

Table 8 shows the results for saturated ORC with R141B. The highest exergy destruction ratio belongs to evaporator due to having a high heat load. Second is turbine and the lowest exergy destruction ratio occurs in pump. Avoidable exergy destruction is the highest in the economizer then turbine. Pump has mostly avoidable exergy destruction. Turbine has the highest exergy efficiency among all other components and the lowest is in preheater. The most expensive part is also turbine in this system and most of this cost is unavoidable. Similar comments can be made on real and avoidable total cost of investment of heat exchangers with the superheated ORC system. The highest real, unavoidable and avoidable costs of exergy destruction belong to economizer in this case. Avoidable costs of exergy destruction are higher than avoidable total investment costs for all components except turbine. In exergetic point of view, improvement efforts should focused be on economizer, turbine, evaporator, condenser, preheater, and pump respectively. However, in advanced exergoeconomic point of view, improvement efforts should be focused on turbine, economizer, evaporator, condenser, pump, and preheater respectively.

Detailed results of advanced exergy and exergoeconomic analyses applied to superheated ORC with R113 are shown in Table 9. Exergy analysis shows that the highest exergy destruction ratio belongs to economizer then evaporator while the smallest is at pump. The highest exergy efficiency is calculated in the turbine and the lowest in the economizer. The most expensive part of the system is turbine as total investment cost and it is mostly unavoidable. Defining a small change in minimum temperature difference for heat exchanger does not affect its total investment cost largely. 
Table 8. Results of Advanced exergy and exergoeconomic analyses for saturated ORC with R141B.

\begin{tabular}{cccccccccccccc}
\hline Component & $\dot{E}_{D, k}$ & $\varepsilon_{k}$ & $y_{D, k}^{*}$ & $\begin{array}{c}\dot{E}_{D, k}^{U N} \\
\mathrm{~kW}\end{array}$ & $\begin{array}{c}\dot{E}_{D, k}^{A V} \\
\mathrm{~kW}\end{array}$ & $\begin{array}{c}\dot{Z}_{k} \\
\$ / \mathrm{h}\end{array}$ & $\begin{array}{c}\dot{Z}_{k}^{U N} \\
\$ / \mathrm{h}\end{array}$ & $\begin{array}{c}\dot{Z}_{k}^{A V} \\
\$ / \mathrm{h}\end{array}$ & $\begin{array}{c}c_{F, k} \\
\$ / \mathrm{kWh}\end{array}$ & $\begin{array}{c}\dot{C}_{D, k} \\
\$ / \mathrm{h}\end{array}$ & $\begin{array}{c}\dot{C}_{D, k}^{U N} \\
\$ / \mathrm{h}\end{array}$ & $\begin{array}{c}\dot{C}_{D, k}^{A V} \\
\$ / \mathrm{h}\end{array}$ & $\begin{array}{c}\dot{C}_{D, k}^{A V}+\dot{Z}_{k}^{A V} \\
\$ / \mathrm{h}\end{array}$ \\
\hline Pump & 2.0164 & 0.8172 & 0.0096 & 0.8452 & 1.1713 & 0.0847 & 0.0508 & 0.0339 & 0.0477 & 0.0961 & 0.0403 & 0.0558 & 0.0897 \\
Preheater & 21.8868 & 0.6593 & 0.1046 & 20.3955 & 1.4913 & 0.3748 & 0.3723 & 0.0025 & 0.0163 & 0.3557 & 0.3314 & 0.0242 & 0.0267 \\
Economizer & 85.3324 & 0.6738 & 0.4077 & 53.4983 & 31.8341 & 0.3784 & 0.3781 & 0.0003 & 0.0163 & 1.3867 & 0.8693 & 0.5173 & 0.5176 \\
Evaporator & 36.0154 & 0.8788 & 0.1721 & 27.4851 & 8.5303 & 1.2960 & 1.2950 & 0.0010 & 0.0163 & 0.5853 & 0.4466 & 0.1386 & 0.1396 \\
Turbine & 43.4403 & 0.8852 & 0.2075 & 25.4640 & 17.9764 & 6.0710 & 5.4639 & 0.6071 & 0.0262 & 1.1360 & 0.6659 & 0.4701 & 1.0772 \\
Condenser & 20.6346 & 0.8128 & 0.0986 & 17.0594 & 3.5752 & 0.5895 & 0.5895 & 0.0000 & 0.0262 & 0.5396 & 0.4461 & 0.0935 & 0.0935 \\
\hline
\end{tabular}

Table 9. Results of Advanced exergy and exergoeconomic analyses for superheated ORC with RI13.

\begin{tabular}{|c|c|c|c|c|c|c|c|c|c|c|c|c|c|}
\hline Component & $\dot{E}_{D, k}$ & $\varepsilon_{k}$ & $y_{D, k}^{*}$ & $\dot{E}_{D, k}^{U N}$ & $\dot{E}_{D, k}^{A V}$ & $\dot{Z}_{k}$ & $\dot{Z}_{k}^{U N}$ & $\dot{Z}_{k}^{A V}$ & $c_{F, k}$ & $\dot{C}_{D, k}$ & $\dot{C}_{D, k}^{U N}$ & $\dot{C}_{D, k}^{A V}$ & $\begin{array}{l}\dot{C}_{D, k}^{A V} \\
+\dot{Z}_{k}^{A V}\end{array}$ \\
\hline & $\mathrm{kW}$ & & & $\mathrm{kW}$ & $\mathrm{kW}$ & $\$ / \mathrm{h}$ & $\$ / \mathrm{h}$ & $\$ / \mathrm{h}$ & $\$ / \mathrm{kWh}$ & $\$ / \mathrm{h}$ & $\$ / \mathrm{h}$ & $\$ / \mathrm{h}$ & $\$ / \mathrm{h}$ \\
\hline Pump & 1.0408 & 0.8181 & 0.0041 & 0.4242 & 0.6165 & 0.0685 & 0.0411 & 0.0274 & 0.0509 & 0.0529 & 0.0216 & 0.0314 & 0.0587 \\
\hline Preheater & 22.1294 & 0.6675 & 0.0865 & 18.8088 & 3.3205 & 0.3609 & 0.3578 & 0.0031 & 0.0162 & 0.3596 & 0.3056 & 0.0540 & 0.0571 \\
\hline Recuperator & 11.5100 & 0.7430 & 0.0450 & 4.7563 & 6.7536 & 0.3626 & 0.3571 & 0.0055 & 0.0285 & 0.3279 & 0.1355 & 0.1924 & 0.1979 \\
\hline Economizer & 61.2235 & 0.6050 & 0.2394 & 31.4702 & 29.7533 & 0.0564 & 0.0562 & 0.0002 & 0.0162 & 0.9948 & 0.5114 & 0.4835 & 0.4837 \\
\hline Evaporator & 55.5927 & 0.8221 & 0.2174 & 43.5853 & 12.0074 & 0.9887 & 0.9881 & 0.0006 & 0.0162 & 0.9033 & 0.7082 & 0.1951 & 0.1957 \\
\hline Superheater & 27.0436 & 0.7531 & 0.1057 & 18.2415 & 88021 & 0.8249 & 0.7400 & 0.0849 & 0.0162 & 0.4394 & 0.2964 & 0.1430 & 0.2279 \\
\hline Turbine & 32.5309 & 0.9025 & 0.1272 & 18.8337 & 13.6972 & 5.8098 & 5.2289 & 0.5810 & 0.0285 & 0.9266 & 0.5365 & 0.3902 & 0.9711 \\
\hline Condenser & 44.6799 & 0.6746 & 0.1747 & 44.4577 & 0.2222 & 0.4645 & 0.4645 & 0.0000 & 0.0285 & 1.2727 & 1.2664 & 0.0063 & 0.0063 \\
\hline
\end{tabular}

Also, small pressure changes in components makes almost no change on total investment cost of the component as it could be observed in condenser, economizer, and evaporator. Due to having the highest total investment cost, turbine has also the highest avoidable investment cost among others. Cost of exergy destruction as well as avoidable and unavoidable parts is under the direct influence of exergy destructions. The highest real, unavoidable and avoidable costs of exergy destruction belong to condenser due to its high exergy destructions and average cost per fuel exergy of the condenser. Avoidable costs of exergy destruction are higher than avoidable total investment costs for all components except turbine. In exergetic point of view, improvement efforts should be focused on economizer, turbine, evaporator, superheater, recuperator, preheater, pump and condenser respectively. However, in advanced exergoeconomic point of view, improvement efforts should be focused on turbine, economizer, superheater, recuperator, evaporator, pump, preheater and condenser respectively.

\section{Conclusions}

In this paper, saturated and superheated ORC WHR systems with different working fluids have been investigated by employing exergy exergoeconomic, advanced exergy and advanced exergoeconomic analyses. Results for overall systems show that R113 is the most suitable organic fluid for superheated ORC. Detailed results of cycle combinations are also presented. And it is revealed that turbine is the most expensive part of the overall system and the highest cost of exergy destruction belongs to condenser. R141B is the most favorable organic fluid for saturated ORC. A slight difference between R141B and R601A has been observed. Turbine is also the most expensive component in this system. On the other hand, economizer has the highest values of cost of exergy destructions. Comparison between these two ORC systems reveals that,

- net power output of saturated ORC is higher

- exergetic efficiency of saturated ORC is higher

- exergy destruction of saturated ORC is lower

- unavoidable exergy destruction of saturated ORC is lower

- avoidable exergy destruction of saturated ORC is lower

- total, avoidable and unavoidable investment costs of saturated ORC are lower

- real, avoidable and unavoidable costs of exergy destruction of saturated ORC are lower than superheated ORC system with R113.

It could be concluded that saturated ORC with working fluid R141B would be a better application for marine power plant WHR system.

Advanced exergy based analyses could be considered as the decision criteria when a new system is designed or for retrofits of an actual system. It may be difficult to determine improvement potential with respect to exergy or economy of a system due to interactions among system components. Advanced exergy based analyses may help to decide how improvement efforts should be directed on components or overall system for recent or future applications.

$\begin{array}{cl}\begin{array}{c}\text { Nomenclature } \\ \text { ASHRAE: }\end{array} & \begin{array}{l}\text { American Society of Heating, } \\ \text { Refrigerating and Air-Conditioning } \\ \end{array} \\ \text { Engineers } \\ \dot{C}: & \text { Exergy Cost Rate } \\ \text { CEPCI: } & \text { Chemical Engineering Plant Cost Index } \\ \dot{E}: & \text { Exergy Rate } \\ \text { Exh: } & \text { Exhaust } \\ \text { EEDI: } & \text { Energy Efficiency Design Index }\end{array}$




\begin{tabular}{|c|c|}
\hline GHG: & Green House Gas \\
\hline h: & Enthalpy \\
\hline IMO: & International Maritime Organization \\
\hline JW: & Jacket Water \\
\hline MCR: & Maximum Continuous Rating \\
\hline MEP: & Mean Effective Power \\
\hline$\dot{m}:$ & Mass Flow Rate \\
\hline ORC: & Organic Rankine Cycle \\
\hline P: & Pressure \\
\hline PEC: & Purchased Equipment Cost \\
\hline$\dot{Q}:$ & Heat \\
\hline s: & Entropy \\
\hline SFC: & Specific Fuel Consumption \\
\hline SEEMP: & $\begin{array}{l}\text { Ship Energy Efficiency and Management } \\
\text { Plan }\end{array}$ \\
\hline SW: & Seawater \\
\hline $\mathrm{T}:$ & Temperature \\
\hline VLCC: & Very Large Crude Carrier \\
\hline$\dot{W}:$ & Power \\
\hline WHR: & Waste Heat Recovery \\
\hline$y^{*}:$ & Exergy Destruction Ratio \\
\hline$\dot{Z}:$ & Investment Cost Rate \\
\hline$\varepsilon:$ & Exergy Efficiency \\
\hline \multicolumn{2}{|c|}{ Subscripts: } \\
\hline 0: & Reference Condition \\
\hline App: & Approach \\
\hline Circ: & Circulation \\
\hline Cold: & Cold Side \\
\hline D: & Destruction \\
\hline F: & Fuel \\
\hline hot: & Hot Side \\
\hline $\mathrm{j}:$ & Stream \\
\hline $\mathrm{k}$ : & Component \\
\hline Min: & Minimum \\
\hline P: & Product \\
\hline Th: & Theoretical \\
\hline tot: & Total, Overall \\
\hline Sup: & Superheated Cycle \\
\hline Sat: & Saturated Cycle \\
\hline \multicolumn{2}{|c|}{ Superscripts: } \\
\hline AV: & Avoidable \\
\hline UN: & Unavoidable \\
\hline
\end{tabular}

\section{References}

[1] R. K. Pachauri, et al., Climate Change Synthesis Report. Contribution of Working Groups I, II and III to the Fifth Assessment Report of the Intergovernmental Panel on Climate Change, 2014.

[2] T. Smith, et al., Third IMO GHG Study, International Maritime Organization (IMO), London, 2014.

[3] Z. Bazari, T. Longva, "Assessment of IMO mandated energy efficiency measures for international shipping," International Maritime Organization, 2011.

[4] Ø. Buhaug, et al., Second IMO GHG Study. International Maritime Organization (IMO), London, UK, 2009.

[5] MARPOL IMO. (2006). Consolidated Edition 2006, MARPOL Annex VI: Regulations for the prevention of air pollution from ships. London: International Maritime Organization, 2006.

[6] F. Baldi, \& C. Gabrielii, “A feasibility analysis of waste heat recovery systems for marine applications," Energy, doi:10.1016/j.energy.2014.12.020.
[7] MAN Diesel\&Turbo., 2014, Waste heat recovery system (WHRS) for reduction of fuel consumption, emissions and EEDI. Kopenhagen, Denmark.

[8] S. Alvik, M. S. Eide, O. Endresen, P. Hoffmann, T. Longva, "Pathways to low carbon shipping-abatement potential towards 2030", TRID, 2009.

[9] Wärtsilä. Solution for merchant vessels. In W. r. Corporation (Ed.), 2010.

[10] MAN Diesel Turbo., 2014, Thermo efficiency system for reduction of fuel consumption and $\mathrm{CO}_{2}$ emission. Kopenhagen, Denmark,.

[11] G. Shu, et al., 2015, “ A review of waste heat recovery on two-stroke IC engine aboard ships," Renewable and Sust. En. Rev., doi:10.1016/j.rser.2012.11.034.

[12] C. Sprouse III, C. Depcik, 2012, "Review of organic Rankine cycles for internal combustion engine exhaust waste heat recovery," Applied Thermal Engineering, doi:10.1016/j.applthermaleng.2012.10.017

[13] I. Vaja, A. Gambarotta, 2009, "Internal Combustion Engine (ICE) bottoming with Organic Rankine Cycles (ORCs)," Energy, doi:10.1016/j.energy. 2009.06.001.

[14] K. K. Srinivasan, P. J. Mago, S. R. Krishnan, 2010, "Analysis of exhaust waste heat recovery from a dual fuel low temperature combustion engine using an Organic Rankine Cycle," Energy, doi:10.1016/j.energy.2010.02.018.

[15] H. Tian, G. Shu, H. Wei, X. Liang, L. Liu, 2012, "Fluids and parameters optimization for the organic Rankine cycles (ORCs) used in exhaust heat recovery of Internal Combustion Engine (ICE), ” Energy, doi:10.1016/j.energy.2012.09.021.

[16] S. Zhu, K. Deng, S. Qu, 2013, "Energy and exergy analyses of a bottoming Rankine cycle for engine exhaust heat recovery," Energy, doi:10.1016/j.energy.2013.06.031.

[17] P. J. Mago, L. M. Chamra, 2008, "Exergy analysis of a combined engine-organic Rankine cycle configuration," Proceedings of the Institution of Mechanical Engineers, Part A: J. Power Energy, doi:10.1243/09576509JPE642.

[18] E. H. Wang, et al., 2011, "Study of working fluid selection of organic Rankine cycle (ORC) for engine waste heat recovery," Energy, doi:10.1016/j.energy.2011.03.041.

[19] E. H. Wang, et al., 2012, "Performance analysis of a novel system combining a dual loop organic Rankine cycle (ORC) with a gasoline engine," Energy, doi:10.1016/j.energy.2012.04.006.

[20] B. C. Choi, Y. M. Kim, 2013, "Thermodynamic analysis of a dual loop heat recovery system with trilateral cycle applied to exhaust gases of internal combustion engine for propulsion of the 6800 TEU container ship," Energy, doi:10.1016/j.energy.2013.05.017.

[21] E. Yun, H. Park, S. Y. Yoon, K. C. Kim, "Dual parallel organic Rankine cycle (ORC) system for high efficiency waste heat recovery in marine application," $J$. Mechanical Science and Technology, 29, 2509-2515, 2015.

[22] D. S. A. Bellolio, V. Lemort, P. Rigo, “Organic Rankine cycles systems for waste heat recovery in marine applications," in the International Conference on 
Shipping in Changing Climates, Glasgow, 24-26th November, 2015.

[23] J. Song, Y. Song, C.-W. Gu, 2015, “Thermodynamic analysis and performance optimization of an Organic Rankine Cycle (ORC) waste heat recovery system for marine diesel engines," Energy, doi:10.1016/j.energy.2015.01.108.

[24] M.-H. Yang, R.-H. Yeh, 2014, “Analyzing the optimization of an organic Rankine cycle system for recovering waste heat from a large marine engine containing a cooling water system," Energy Conversion and Management, doi:10.1016/j.enconman.2014.09.044.

[25] M.-H. Yang, R.-H. Yeh, 2015, “Thermodynamic and economic performances optimization of an organic Rankine cycle system utilizing exhaust gas of a large marine diesel engine," Applied Energy, doi:10.1016/j.apenergy.2015.03.083.

[26] M.-H. Yang, R.-H. Yeh, 2015, “Thermo-economic optimization of an organic Rankine cycle system for large marine diesel engine waste heat recovery," Energy, doi:10.1016/j.energy.2015.01.036.

[27] M.-H. Yang, 2015, “Thermal and economic analyses of a compact waste heat recovering system for the marine diesel engine using transcritical Rankine cycle," Energy Conversion and Management doi:10.1016/j.enconman.2015.10.050.

[28] M. Kalikatzarakis, C. A. Frangopoulos, "Multi-criteria selection and thermo-economic optimization of Organic Rankine Cycle system for a marine application," Int. J. Thermodynamics, 18, 133-141, 2015.

[29] T. Koroglu, O. S. Sogut, 2017, “Advanced exergy analysis of an organic Rankine cycle waste heat recovery system of a marine power plant," J. Thermal Engineering, doi:10.18186/thermal.298614.

[30] A. Bejan, M. J. Moran, G. Tsatsaronis, Thermal design and optimization: John Wiley and Sons, 1996.

[31] F. Baldi, F. Ahlgren, T.-V. Nguyen, C. Gabrielii, \& K. Andersson, "Energy and exergy analysis of a cruise ship," in the The 28th ECOS: International Conference on Efficiency, Cost, Optimization, Simulation and Environmental Impact of Energy Systems, 2015.

[32] F. Baldi, H. Johnson, C. Gabrielii, K. Andersson, 2014, "Energy and exergy analysis of ship energy systems-the case study of a chemical tanker," in the 27th ECOS, International Conference on Efficiency, Cost, Optimization, Simulation and Environmental Impact of Energy Systems.

[33] P. Marty, J.-F. Hétet, D. Chalet, P. Corrignan, "Exergy analysis of complex ship energy systems," in the 7th International Exergy, Energy and Environment Symposium, Valenciennes, France. 27-30 April, 2015.

[34] T. J. Kotas, The exergy method of thermal plant analysis: Butterworth Publishers,Stoneham, MA, 1985.

[35] T. Morosuk, G. Tsatsaronis, 2009, “Advanced exergy analysis for chemically reacting systems-application to a simple open gas-turbine system" International Journal of Thermodynamics, 12, 105-111.

[36] T. Koroglu, O .S. Sogut, 2015, "Advanced exergy analysis of a Marine Diesel Engine waste heat recovery system," in the International Conference on Shipping in Changing Climates, Glasgow, 24-26th November, 2015.

[37] G. Tsatsaronis, T. Morosuk, 2007, "Advanced exergoeconomic evaluation and its application to compression refrigeration machines," in the ASME 2007 International Mechanical Engineering Congress and Exposition.

[38] F. Petrakopoulou, Comparative evaluation of power plants with CO2 capture: thermodynamic, economic and environmental performance. (Dr.-Ing), Berlin Technical University, Berlin, 2010.

[39] F. Cziesla, G. Tsatsaronis, Z. Gao, 2006, “Avoidable thermodynamic inefficiencies and costs in an externally fired combined cycle power plant," Energy, 31, 14721489.

[40] A. Gungor, G. Tsatsaronis, H. Gunerhan, \& A. Hepbasli, 2014, "Advanced exergoeconomic analysis of a gas engine heat pump (GEHP) for food drying processes," Energy Conversion and Management, doi:10.1016/j.enconman.2014.11.044.

[41] F. Petrakopoulou, G. Tsatsaronis, T. Morosuk, A. Carassai, 2012, "Advanced exergoeconomic analysis applied to a complex energy conversion system.," $J$. Engineering of Gas Turbines and Power, 134, 031801.

[42] M. Tan, A. Keçebaş, 2014, "Thermodynamic and economic evaluations of a geothermal district heating system using advanced exergy-based methods," Energy Conversion and Management, 77, 504-513.

[43] G. Tsatsaronis, T. Morosuk, 2008, “A General ExergyBased Method for Combining a Cost Analysis With an Environmental Impact Analysis: Part I-Theoretical Development," in the ASME 2008 International Mechanical Engineering Congress and Exposition.

[44] G. Tsatsaronis, M.-H. Park, 2002, “On avoidable and unavoidable exergy destructions and investment costs in thermal systems," Energy Conversion and Management, 43, 1259-1270.

[45] Y. A. Cengel, M. A. Boles, Thermodynamics : an engineering approach. New York: McGraw Hill, 2015.

[46] T. Morosuk, G. Tsatsaronis, "A new approach to the exergy analysis of absorption refrigeration machines," Energy, 33, 890-907, 2008.

[47] W. D. Seider, J. D. Seader, D. R. Lewin, Product and Process Design principles, Synthesis, Analysis and Evaluation, $2^{\text {nd }} e d$. New York: John Wiley \& Sons, 2003.

[48] C. Deniz, 2015, “Thermodynamic and Environmental Analysis of Low-Grade Waste Heat Recovery System for a Ship Power Plant," Int. J. Energy Science, 5, 23-34.

[49] STEAG. (2015). EBSILON®Professional (Version 11). Essen, Germany: STEAG Energy Services GmbH.

[50] F. Petrakopoulou, G. Tsatsaronis \& T. Morosuk, 2011, "Exergoeconomic Analysis of an Advanced Zero Emission Plant," J. Engineering for Gas Turbines and Power, doi:10.1115/1.4003641.

[51] H. Chen, D. Y. Goswami, E. K. Stefanakos, 2010, “A review of thermodynamic cycles and working fluids for the conversion of low-grade heat," Ren. Sust. En. Rev., doi:10.1016/j.rser.2010.07.006.

[52] U. Larsen, L. Pierobon, F. Haglind, C. Gabrielii, 2013, "Design and optimisation of organic Rankine cycles for waste heat recovery in marine applications using the 
principles of natural selection," Energy, doi:10.1016/j.energy.2013.03.021.

[53] A. S. Panesar, R. E. Morgan, N. D. D. Miché, M. R. Heikal, 2013, "Working fluid selection for a subcritical bottoming cycle applied to a high exhaust gas recirculation engine," Energy, doi:10.1016/j.energy.2013.08.015.

[54] N. F. Tumen Ozdil, M. R. Segmen, A. Tantekin, "Thermodynamic analysis of an Organic Rankine Cycle (ORC) based on industrial data," 2015, Appl. Therm. Eng., doi:10.1016/j.applthermaleng.2015.07.079.

[55] ASHRAE. (2013). Designation and Safety Classification of Refrigerants ANSI/ASHRAE Standard 34-2013. Retrieved from ashrae.org.

[56] F. Petrakopoulou, G. Tsatsaronis, T. Morosuk, \& A. Carassai, 2012, "Conventional and advanced exergetic analyses applied to a combined cycle power plant," Energy, 41(1), 146-152.

[57] B. Boundy, S. W. Diegel, L. Wright, \& S. C. Davis, Biomass Energy Data Book: Edition 4: Oak Ridge National Laboratory, 2011.

[58] P. Stephan, et al., VDI Heat Atlas (2 ed.). Berlin Heidelberg: Springer-Verlag Berlin Heidelberg, 2010.

[59] F. Petrakopoulou, G. Tsatsaronis, \& T. Morosuk, 2013, "Evaluation of a power plant with chemical looping combustion using an advanced exergoeconomic analysis," Sustainable Energy Technologies and Assessments, doi:10.1016/j.seta.2013.05.001. 